\title{
Exploratory Study on the Consumer's Awareness of the Concept of Green Marketing in the Saudi Market
}

\author{
Ahmed Osman Ibrahim Ahmed ${ }^{1} \&$ Somaia Osman Mohamed Abdelgadir ${ }^{2}$ \\ ${ }^{1}$ Faculty of Applied Studies and Community Service, Imam Abdul Rahman bin Faisal University, Saudi Arabia \\ ${ }^{2}$ Faculty of Economics and Administrative Sciences, Imam Mohammed bin Saud Islamic University, Saudi \\ Arabia \\ Correspondence: Somaia Osman Mohamed Abdelgadir, Faculty of Applied Studies and Community Service, \\ Imam Abdul Rahman bin Faisal University, Saudi Arabia. E-mail: somaiagadir@hotmail.com
}

Received: April 5, 2018

doi:10.5539/ijbm.v13n7p33
Accepted: May 21, 2018

Online Published: June 15, 2018

URL: https://doi.org/10.5539/ijbm.v13n7p33

\begin{abstract}
The study dealt with an explanatory study about the extent to which the Saudi consumer understands the concept of green marketing in the Saudi market. As green marketing plays an important role in the social and ethical responsibility of marketing .One of the main hypothesis, is that, there is a follow up, and knowledge of the protective administrative means, followed by the company, and consumer's protection. The objective of the research is to identify the extent to which consumer awareness and understanding of the concept of green marketing, in protecting himself and the society. The descriptive and analytical statistical methodology has been followed to present the study data. The most important findings' are that the Saudi consumer has a high sense of responsibility towards the environment in general. Prioritizing their preferences to select products in purchasing decisions. The most important recommendations are to encourage consumers to adopt environmentally friendly values and culture through promotional messages directed at the consumer, by companies.
\end{abstract}

Keywords: green marketing, perception, consumer protection

\section{Introduction}

Since the beginning of the sixties of the last century, the world began to express great concern and anxiety about environmental issues, which are of concern to the entire humanitarian community. This concern grew significantly in subsequent years, despite global technological advances and the entry of the third millennium. As arose complex environmental issues such as; global climate change, depletion of natural resources, air pollution caused by toxic gases, environmental damage caused by industrial waste and residues, forest depletion, acid rain, damage to the ozone layer in the atmosphere, leakage of toxic substances that affect biological activity, production and marketing of environmentally and human harmful substances, as well as human misuse of the environment.

Green marketing is a translation of the requirements of social and ethical responsibility for marketing. Green marketing is about the commitment of business organizations, to deal with environmentally friendly goods, that are harmless to society and the natural environment and hence to carry out marketing activities within the framework of strong commitment to environmental responsibility, and within specific controls to ensure the preservation of the natural environment. Green marketing companies have a responsibility to develop customers' environmental awareness through the products, and promotions accompanying their products, so that these customers can deal with benefits resulting from the use of those products for themselves, or the environment in general, or even to ascertain those benefits, especially if they have ideas and prejudices about green marketing.

\subsection{Research Problem}

The concept of green marketing emerged because of the establishments' interest in the environment in which they operate, which was due to their understanding of the important fact that their survival and continuity lies in the harmonization of the interest of the consumer and the interest of society. Survival and long-term growth depends in a safe and healthy environment. Hence, attention has been paid to the new marketing model known as green marketing, as a marketing approach that provides solutions to these social impacts and negative environmental and it is centered on the strong commitment of responsibility towards the environment in the practice of marketing activities. The adoption of the concept of green marketing is an urgent necessity for business organizations. It helps 
them achieve many advantages, such as conserving natural resources- harming the environment, achieving satisfaction and prosperity for consumers by offering safe and environmentally friendly products. And to make less percentage of damage, which leads to the optimal use of the primary resources used in production and improving the production and marketing processes within the establishment.

The main reason for this research is the desire to explore the awareness of the concept and importance of green marketing in Saudi society.

\subsection{The Main Research Problem Is}

What is the role of awareness of the Saudi consumer of the concept of green marketing to provide protection for himself and the community?

\subsection{Research Hypotheses}

1 There is a relationship between the follow-up and knowledge of preventive management methods used by companies and between consumer protections.

2 There is a relationship between awareness and knowledge of the consumer and how to protect him for himself.

3 There is a relationship between educational level and increasing consumer awareness.

\subsection{Research Objectives}

1. To understand the extent does the consumer contributes to the concept of green marketing, in protecting himself and the society.

2. To know the contribution of consumer awareness and understanding of the concept of green marketing in influencing their purchasing decisions. The extent to which the consumer adopts an environment-friendly.

3. Consumption culture that supports green marketing.

4. Building a database of information and data, to assist in further studies in this regard.

5. Submit proposals and recommendations that contribute to solving the research problem

\subsection{Research Importance}

The importance of research stems from the importance of the same subject (green marketing). Most of the resources provided by nature are not all renewable resources, especially energy resources, so it is necessary to create an environment friendly culture that preserves its natural resources and uses renewable energy as best possible. To be addressed through cooperation among all groups of society (individuals, groups, organizations). In addition to the lack of research contributions in this area, with regard to the Saudi business environment, this gave this study more importance.

\section{Research Methodology}

This research adopted the descriptive analytical methodology, that describes phenomena and events, specifically the case study methodology, and used the statistical method to analyze data and information.

\subsection{Data and Information Collection Tools}

1. Secondary data: books and references, articles, scientific journals, master's thesis.

2. Preliminary data: observation and questionnaire.

\subsection{Research Limits}

1. Spatial boundaries: Riyadh City - Saudi Arabia.

2. Time limits: $1437-1432$.

\subsection{Community and Research Sample}

The research community is represented by a consumer audience in the city of Riyadh. The following equation was used to arrive at a representative sample of the research community:

$$
\mathrm{n}=(2 * 6000000) /((6000000-1) / 16(+2)
$$

A simple random sample of consumers was selected with a total of 31 in the Riyadh region. As illustrated, the survey is aimed at finding the way to crystallize the concept of the subject.

\section{Previous Studies}

Research entitled (The reality of marketing green medicine in the compound of Sidal, Algeria); the aim of the research was to shed light on the reality of green marketing in the pharmaceutical complex of Sidal. The problem 
of the research was to try to understand the reality of the practice of green marketing in the company and its commitment to social and marketing responsibility towards consumers and society. Fishing the). The aim of the research was to highlight the concept of green marketing, and its various aspects .It was based on several hypotheses (green marketing is a priority of the Sidal complex). The aim of the research was to highlight the concept of green marketing and its various components, and this goal meets one of the objectives of this study that we have prepared (Abdul Rahman, 2014)

2. Research entitled "The relationship between green marketing and cleaner production strategy: A survey study of the views of a sample in Karbala Cement Factory." The aim of the research was to identify the extent of awareness of the organizations working on the concept of green marketing and cleaner production strategy. Research findings, were that there is a strong positive correlation between the dimensions of green marketing and cleaner production strategy. (Majeed and Shaker)

3. A study entitled "Activating Green Marketing in the trends of the Market-Based Environment in Iraqi Business Organizations: A Survey Study". The problem of this study was -due to the researcher's understanding -on the reality of the work of a sample of Iraqi labor organizations. The research was based on a hypothesis that emphasizes what organizations should do in order to adopt green initiatives; one of the main conclusions of the research is that business organizations in developed countries have adopted a new approach in the context of green marketing by employing a market-based environment. (Abd AlRida, 2008)

\section{Theoretical Framework}

\subsection{Marketing Concept}

Founded in 1960, the American Marketing Association defines marketing as the business that directs the flow of goods and services from product to consumer, as it was also defined it in 1985as: "Marketing is the process of planning and implementing policies creating, pricing, promoting, distributing ideas, goods and services to achieve exchanges which serves the goals of the individual and the organization. Another definition is that "William Statton" says that, it is a system in which the range of activities that work to plan, price, promote and distribute goods and services to consumers is intertwined (Alawash, 2011).

\subsection{Importance of Marketing}

Marketing is the means by which the organization can recover the money spent and achieve a return on it. This means that without marketing the institutions cannot continue to operate. The success of the marketing plan means increasing sales and thus maximizing the profits of the organization.

The success of the marketing activity in the institution, leads to the continuation and prosperity, and failure will create a lot of problems, including reduced sales and therefore the decline in profits. From the society's point of view, marketing is clear and important, as long as it allows people to enjoy high levels of well-being. The consumer has different needs and desires that he tries to satisfy as much as possible. The task of satisfying the needs and desires lies with the marketing and if the latter does not succeed in performing its job on a satisfactory basis, i.e., when it fails to provide the goods and services required by the members of the community, we will find a clear decline in the allocation and distribution of resources to different uses and this means not satisfying the needs and desires of society. In addition, the marketing activity creates a number of jobs, in which the working members of the community work. If the industrial establishments in a field fail to market their production, they will be forced to reduce their production capacity and, on the other hand, eliminate a large number of workers (Dahmani, 2002).

\subsection{Marketing Objectives}

(a) Predicting the wishes and needs of the members of the community, and undertaking the necessary activities to achieve this.

(b) Achieving a high level of consumer or customer satisfaction.

(c) Maintaining the development of the competitive position of the Organization.

(d) Maximizing the organization's share in the market, or from the sales of the industry. This share is measured as follows:

(e) Achieving a certain number of profits arising from the sale, the marketing agent is an engineer whose primary task is to generate profits from sales (Shafig, 2006)

Elements of marketing strategy:

The following is a brief explanation of the key elements: market target marketing mix elements and marketing 
environment.

\section{a. Target Market}

The focal point in marketing activities is the consumer. The overall strategy is to set out many details to determine the target markets. The target market is a group of individuals to whom the company directs its product through a strategy designed to satisfy and meet specific needs (Shafig, 2006)

\section{b. Marketing Mix Variables}

After the marketing manager has identified the target market, the company directs all its activities to meet the needs of that target sector profitably through four key strategies: product strategy, price strategy, promotion strategy, and distribution strategy. These elements constitute, what is known as the marketing mix, a combination of four strategic elements to match the needs and preferences of a specific target market, each of which is variable in the mix and determines the degree of marketing success (Shafig, 2006)

\section{c. The marketing environment}

Marketing decisions regarding target markets and marketing mix variables are not made in a vacuum. Rather, they must take into account the dynamic and continuous nature of the five dimensions of the marketing environment (in Figure No.), these dimensions are: demographic, competition, legal, political, economic, cultural and social. (Shafig, 2006)

\subsection{Green Marketing Concept}

Green marketing can be seen as a translation of the social and ethical responsibility of marketing, which is seen as a response to the increasing environmental challenges of the new era. This marketing approach comes in line with the growing global interest in consumer protection and the rights of people to live in a safe and clean environment that has gone through several stages since the 1960s So far, these movements have paved the way for the emergence of green marketing in the last half of the decade. Green marketing revolves around the commitment of business organizations to deal with environmentally friendly goods (goods that are not harmful to society and the natural environment) and to carry out marketing activities within the framework of the commitment to environmental responsibility and within specific controls to ensure the preservation of the natural environment and not to harm it (Mohammad, 2014).

Social marketing is the actual translation of the modern concept of marketing, which is aware of the needs, desires and tastes of consumers or users of goods and services, and attempts to meet or satisfy them. Social marketing focuses on the importance of social programs, with main purpose, to assist consumers when any violations of their rights occur (Murad, 2011).

Green Marketing: An integrated system approach aimed at influencing customers' preferences in a way that leads them to seek environmentally friendly products and adjust their consumer habits in line with this, and to provide an integrated marketing mix that is based on innovation in a way that satisfies this trend. (Thamer, 2007).

Table 1. The fundamental differences between traditional and green marketing

\begin{tabular}{|c|c|c|}
\hline Item & Traditional Marketing & Green Marketing \\
\hline Target & Growth and increase of sales & $\begin{array}{l}\text { Considering the requirements of the } \\
\text { environment and society with the growth } \\
\text { goal }\end{array}$ \\
\hline Available resources & Making them positive for the sake of sales & maintaining and rationalizing \\
\hline Mix tools & harness them to make profits & adapting to the environment \\
\hline Relationship with the customer & $\begin{array}{l}\text { Responding to customers' needs without taking } \\
\text { into account the requirements and needs of the } \\
\text { environment }\end{array}$ & $\begin{array}{l}\text { Guide customers and protect them from } \\
\text { wrong consumer habits that have negative } \\
\text { impacts on the environment and society }\end{array}$ \\
\hline Channels of distribution & One-way & Two-ways \\
\hline
\end{tabular}

Source: Mohammed Hamouda, The Relationship Between Adopting the Concept of Green Marketing and Marketing Performance, Al-Azhar University, 2014. 


\subsubsection{Social Responsibility}

Social responsibility has become part of the interaction with the environment in all its variants, as well as achieving its traditional strategic goals in profit, survival and growth. Marketing activity may be the most important element in the organization's communication with the society through its various goods and services. (Business and community organizations), and this relationship has been reflected at different stages of social responsibility (Mohammad, 2014).

\subsection{Reasons for the Emergence of Green Marketing}

1. Increasing attention to the ethics of management, and in all aspects of the administrative process, its activities and the effective role in improving the performance of the administrative process in the organization.

2. The role of society and the state in promoting social values and ethics in the field of business has been embodied by social and environmental organizations on the one hand, and legislation and government laws that are directed in this direction on the other.

3. The requirements and pressures imposed by the government on organizations to commit to, and protect the environment from damage. This fact has emerged in environmental systems and organizations, foremost of which are ISO 19000 series and Greenpeace organizations.

4. Emphasize the importance of compliance with legislation and laws concerning the safety of the product and prevent the arrival of the product that is not compatible with the customer.

5. The role of community satisfaction and stakeholders in promoting the sustainable competitive advantage of business organizations.

6. Urge organizations to use the means and take measures to prevent environmental damage of various kinds.

7. forming an organizational and social culture that makes customers accept products that do not generate environmental damage (Mohammad: 2014)

Dimensions of Green Marketing: the green marketing approach is based on four key dimensions, including.

1- The elimination of the concept of waste (or reduction): The traditional concept of dealing with waste and industrial residues has changed in green marketing. The focus is on the design and production of waste-free (or minimum) commodities rather than how to dispose of them, That is, what matters is not what we should do with waste, but how to produce goods without waste.

2- Restructuring the concept of the product: It is to keep abreast of the production technology of the concept of environmental commitment, so that the production depends heavily on raw materials that are environmentally friendly and the minimum consumption thereof. As well as the need to rotate the same products after the end of the consumer use, especially durable ones, to return to the factory at the end, which can be dismantled and returned to industry again (in a closed loop). The packaging is based on environmentally friendly and recyclable raw materials.

3- Clarity of the relationship between price and cost: The price of the product must reflect its real cost or be close to it. This means that the price of the commodity (the real cost to the consumer) must equal the value obtained from the commodity, including the added value of the product being green.

4- Making environmental trends profitable: Many organizations have recognized that green marketing is a market opportunity that may give the organization a competitive advantage and perhaps sustainable. In fact, most organizations compete in the market to achieve rapid gains, regardless of the negative effects on the environment. The competition in the market recognizes that this is a strategic competitive outlet, which can take the organization into another kind of competition, especially as environmental awareness among consumers grows and gradually transforms them into green consumers. One of the advantages of this strategic approach is that formal and informal bodies promote environmental trends naturally and continuously through various media. This includes free assistance and support from these agencies to the promotion efforts of organizations that adopt a green marketing approach (Sami, 2006)

\subsection{The Importance of Green Marketing}

Green marketing is benefit for organizations that adopt this concept, the most important of which are the following:

a. Improving the reputation of the organization: The organization's reputation reflects the developments of its client group such as owners, customers, suppliers, employees, banks, NGOs, consumers, and the government. 
b. Achieving Competitive Advantage: The green marketing approach is expected to open new horizons and attractive market opportunities to the organizations that exercise them, thus allowing them to avoid traditional competition and therefore have a competitive edge in the market. Ottman believes that, green marketing helps to achieve competitive advantage by creating environmental values for customers and the establishment of environmentally friendly market segments, making the organization ahead of its environmental competitors in the market.

c. Making profits: The use of highly efficient production methods, which are based on fewer raw materials or recycling, or energy availability, will result in cost savings and hence more profits.

d. Increasing share: In the face of increasing environmental problems, consumer loyalty to the market brand will decline over time, and consumers will switch to environmentally friendly products and packaging, so there is a chance. Xi to organizations that adopt green marketing to increase their market share.

e. Personal incentives: Green marketing provides opportunities and incentives for managers responsible for the organization to follow modern and effective methods in providing environmentally friendly products. This is a personal contribution to the preservation of the environment (Halima: 2011)

\subsection{Green Marketing Mix Elements}

Although the traditional marketing mix is still considered as the foundation of green marketing, it has come under critics' attack in the new direction of green marketing. Where critics believe that, it leads to some negative environmental effects that are not consistent with green marketing concepts. For example, critics argue that it focuses on satisfying consumer needs regardless of environmental considerations, such as the provision of some environmentally harmful goods with waste of natural resources and the use of non-environmentally friendly materials. Green marketing focuses on the environmental dimension and social responsibility in all marketing decisions related to the green marketing mix. In this sense, the green marketing mix includes new elements, classified within two dimensions - internal and external, as follows: First: the external green marketing mix, consisting of seven elements as follows:

1. Green Customers(People); include customers who are convinced of green marketing philosophy and who want to buy green products

2. (Providers) include suppliers working within the green marketing umbrella who deal with environmentally friendly materials and equipment.

3. (Politicians) are those who believe in green thought, and who influence government decision and who can exercise their political influence in order to pass laws and legislations to support environmental orientation in general.

4. (Pressure groups) are like politicians, in their belief in green thinking and pressure on decision-makers.

5. (Problems and Issues). The organization of business relates to social issues related to environmental commitment and moral and social responsibility.

6. (Prediction) Predicting the problems and environmental changes that the organization can face when undertaking green marketing activities and preparing to deal with them in the future.

7. (Partners), trial to connect FAO partners to issues related to environmental aspects and social responsibility.

Second: the internal green marketing mix, consisting of eight elements as follows:

1. Product: Provide green products to customers, with the need to follow these products during the stages of their life cycle to ensure their use within the environmental orientation.

2. Price: is the pricing of products in line with green consumers. But these prices may have some additions because of the cost of continuous research and development to ensure the use of environmentally friendly materials and new energy sources.

3. Place: using distribution outlets that deal with green products, and are convenient for consumers in terms of accessibility, while ensuring that they carry out recycling procedures within environmental requirements and obligations.

4. Promotion: All promotional activities are included within the environmental orientation, with an emphasis on consumer guidance through environmental posters and guidance information on the safe use of green products (e.g. green advertising).

5. Providing information: The provision and receipt of information (both within and outside the organization) regarding the monitoring of environmental issues to ensure environmental compliance and the organization's survival within the framework of green marketing. 
6. Processes ensure that the minimum energy is used in the production processes while reducing the loss (lost)

7. Policies To adopt policies of encouraging and support the environmental orientation of the organization, and to monitor and evaluate environmental performance on an ongoing basis.

8. People employ environmental-oriented competencies and train human cadres to raise their abilities and skills in the field of environmental commitment (Sami: 2006)

\subsubsection{Consumer Protection}

Unfortunately, some business organizations try to satisfy the needs and desires of consumers in various ways and achieve profits, regardless of the negative effects that may result from it (such as some undesirable consumer patterns harmful to society and the environment).

There are many aspects of this. For example, some organizations sell their products, especially when they are new, at exorbitant prices under the pretext of high expenses during the organization of promotional campaigns and incentive measures. In some cases, the sale price may be eight times the cost or more. Some organizations also cheat on misleading promotions, misleading prices, counterfeiting, lying to the consumer, giving exaggerated information about the advantages and characteristics of the commodity, and trying to convince the consumer to buy goods that are not in need or goods of poor or defective quality.

On the other hand, some organizations promote and sell unhealthy goods such as saturated fat, hormone therapy, harmful preservatives, high-sugar sweets, especially for children, alcohol and smoke, as well as environmentally harmful and hazardous goods, and goods that do not contain minimum safety during use. There are also a lot of programmed goods designed on the basis of the speed of damage to shorten their useful lives and replace them in a short time to maximize the gains (such as some electrical and electronic devices).

The modern marketing system stimulates values and culture of material consumption, so that people are judged by what they own and not by what they represent as people (for example, some people tend to respect and appreciate people who have a luxury house in a luxury place, luxury car, etc., and vice versa).

This trend leads to the frustration of disadvantaged segments of the society, and leads to their sense of deprivation, and the negative social consequences that result. Hence, there has been multiple consumer protection movements since the fifties of the last century aimed at protecting consumer rights and providing the necessary information to enable him to choose the right goods. (Sami, 2006)

\subsection{Basic Rights for the Consumer, Including}

1. Security and safety to protect against harmful goods.

2. Obtain adequate and honest information to protect it from fraud and deception.

3. Freedom of choice with multiple opportunities and honest competition.

4. Expressing the opinion that he takes into account in enacting government laws and regulations.

\section{Field Study}

\subsection{Study Methodology and Procedures}

This chapter describes the methodology of the study, the members of the study community, as well as the tools used in the study, the methods used to prepare it, its validity, and finally the statistical treatments that were relied upon in the analysis of the study.

\subsection{Statistical Methods Used}

After collecting the questionnaire, the researchers emptied and analyzed the data through the Statistical Analysis Program (SPSS). The following statistical methods were used:

Person correlation coefficient: The correlation coefficient (Person) was used to determine the internal consistency of the study instrument and to measure the validity of the terms of the study instrument. As well as to measure the relationship between follow-up and knowledge of preventive management methods used by companies and between consumer protection, and to measure the relationship between consumer awareness and awareness and protection for himself.

Stability coefficient: The Alpha Cranbach coefficient was used to measure the stability of the responses of the research sample, which must be greater than 0.60 , so that we can analyze the questionnaire and accept its results.

Recursive distribution: Tables that summarize the initial data of the research sample and determine the number and percentage of each category. 
F test "One Way Anova" analysis: to measure the relationship between educational level and consumer awareness.

\section{Here is some illustration of how tools were used in the study}

\section{* Verification of the internal consistency of the study tool:}

Pearson correlation coefficients were calculated, between the score of each instrument of the study instrument, and the degree of all the terms contained in the study instrument, using the Pearson correlation coefficient. The degree of correlation of all the terms of the questionnaire was statistically significant at (0.05) or (0.01). Indicating the strength of the correlation between each of the questionnaire expressions and the degree of all the questionnaire expressions (see annexes), which means consistency and credibility among the questionnaire expressions.

\section{* Stability of the study tool:}

The Cranbach Alpha coefficient was used to confirm the stability of the study tool, and to measure the accuracy of the study results. The value of alpha (0.741) for the questionnaire terms is statistically acceptable.

Prior to the presentation of the results of the study was reached, some of the characteristics of the demographic associated with the study sample, which can be useful in future studies, by linking them and home some of the statements in the questionnaire to identify the relationship between these demographic variables and some variables.

* Characteristics of study sample members:

Some independent variables related to the functional and personal characteristics of the study sample were analyzed (age, educational level, gender).

1- Distribution of the sample of the study according to the age variable:

The analysis showed that $21 \%$ of the study sample ranged between 21 and 30 years of age, with $67.7 \%$ being the highest group, while (4) of them were under the age of 20 years, 12.9\%, while (3) More than 40 years, between 31 and 40 years, reaching $19.7 \%$, the lowest category.

2- Distribution of the sample of the study according to the variable level of education:

The analysis of educational level data showed that the vast majority of the sample of the study was of educational; diploma/graduate level with a rate of $71 \%$, while the average level of graduates of Intermediate/secondary was $16.1 \%$, while the percentage of the elementary educational level

Was $9.7 \%$, while the percentage of those who were postgraduates was $3.2 \%$ of the total study sample?

3 - Distribution of the sample of the study according to gender variable:

The analysis of the gender variable showed that the vast majority of the study sample was female, with a rate of $74.2 \%$, while the percentage of males was $25.8 \%$ of the total sample.

* Presentation of the study results:

This section presents the results of the field study and its discussion by presenting the responses of the sample members, to the terms of the questionnaire and verifying the validity of the study hypotheses as follows:

The first hypothesis: There is a relationship between the follow-up and knowledge of preventive management methods followed by companies and between consumer protection.

Table 2. Arithmetical averages and standard deviations of the terms of follow-up and knowledge of preventive management methods followed by companies

\begin{tabular}{|c|c|c|c|c|c|c|c|c|c|}
\hline No & $\begin{array}{l}\text { Phrase } \\
\text { Degree of approval }\end{array}$ & & $\begin{array}{l}\text { Strongly } \\
\text { agree }\end{array}$ & Agree & Neutral & Disagree & strongly & $\begin{array}{l}\text { Ave } \\
\text { disagree } \\
\text { rage }\end{array}$ & Deviation \\
\hline 1 & $\begin{array}{l}1 \text { The need for business organizations to apply } \\
\text { the concept of green marketing to increase } \\
\text { consumer awareness of social responsibility } \\
\text { and environmental protection trend }\end{array}$ & $\begin{array}{l}\mathrm{Q} \\
\%\end{array}$ & $\begin{array}{l}18 \\
58.1\end{array}$ & $\begin{array}{l}11 \\
35.5\end{array}$ & $\begin{array}{l}1 \\
3.2\end{array}$ & $\begin{array}{l}1 \\
3.2\end{array}$ & $\begin{array}{l}0 \\
0\end{array}$ & 4.08 & 0.982 \\
\hline 2 & $\begin{array}{l}\text { There is a noticeable trend and role of the } \\
\text { State in activating the application of green } \\
\text { marketing in business organizations }\end{array}$ & $\begin{array}{l}\mathrm{Q} \\
\%\end{array}$ & $\begin{array}{l}6 \\
18.8\end{array}$ & $\begin{array}{l}5 \\
15.6\end{array}$ & $\begin{array}{l}16 \\
50\end{array}$ & $\begin{array}{l}5 \\
15.6\end{array}$ & $\begin{array}{l}0 \\
0\end{array}$ & 3.82 & 1.179 \\
\hline 3 & $\begin{array}{lrrr}\text { Increasing consumer } & \text { awareness } & \text { and } \\
\text { awareness of social responsibility } & \text { The }\end{array}$ & $\begin{array}{l}\mathrm{Q} \\
\%\end{array}$ & $\begin{array}{l}13 \\
40.6\end{array}$ & $\begin{array}{l}14 \\
43.8\end{array}$ & $\begin{array}{l}5 \\
15.6\end{array}$ & $\begin{array}{l}0 \\
0\end{array}$ & $\begin{array}{l}0 \\
0\end{array}$ & 3.83 & 1.203 \\
\hline
\end{tabular}




\begin{tabular}{|c|c|c|c|c|c|c|c|c|c|}
\hline & $\begin{array}{l}\text { direction of protecting the environment For } \\
\text { reasons of concern of organizations The need } \\
\text { to apply the concept of green marketing }\end{array}$ & & & & & & & & \\
\hline 4 & $\begin{array}{l}\text { Increasing consumer awareness and } \\
\text { awareness of social responsibility The } \\
\text { direction of protecting the environment For } \\
\text { reasons of concern of organizations The need } \\
\text { to apply the concept of green marketing }\end{array}$ & $\begin{array}{l}\mathrm{Q} \\
\%\end{array}$ & $\begin{array}{l}18 \\
15.3\end{array}$ & $\begin{array}{l}8 \\
25\end{array}$ & $\begin{array}{l}4 \\
12.5\end{array}$ & $\begin{array}{l}2 \\
6.3\end{array}$ & $\begin{array}{l}0 \\
0\end{array}$ & 4.28 & 1.019 \\
\hline 5 & $\begin{array}{l}\text { Saudi business organizations are keen to } \\
\text { design products that meet the requirements of } \\
\text { the environment. }\end{array}$ & $\begin{array}{l}\mathrm{Q} \\
\%\end{array}$ & $\begin{array}{l}7 \\
22.6\end{array}$ & $\begin{array}{l}10 \\
32.3\end{array}$ & $\begin{array}{l}9 \\
29\end{array}$ & $\begin{array}{l}4 \\
12.9\end{array}$ & $\begin{array}{l}1 \\
3.2\end{array}$ & 4.06 & 0.993 \\
\hline 6 & $\begin{array}{l}\text { It is possible to change commercial brand } \\
\text { names for environmental reasons }\end{array}$ & $\begin{array}{l}\mathrm{Q} \\
\%\end{array}$ & $\begin{array}{l}7 \\
22.6\end{array}$ & $\begin{array}{l}11 \\
35.5\end{array}$ & $\begin{array}{l}7 \\
22.6\end{array}$ & $\begin{array}{l}4 \\
12.9\end{array}$ & $\begin{array}{l}2 \\
6.5\end{array}$ & 3.76 & 1.272 \\
\hline 7 & $\begin{array}{l}\text { There is a weakness in the mechanisms used } \\
\text { to enhance the role of organizations in } \\
\text { protecting the environment and increasing } \\
\text { consumer awareness. }\end{array}$ & $\begin{array}{l}\mathrm{Q} \\
\%\end{array}$ & $\begin{array}{l}11 \\
35.5\end{array}$ & $\begin{array}{l}15 \\
48.4\end{array}$ & $\begin{array}{l}5 \\
16.5\end{array}$ & $\begin{array}{l}0 \\
0\end{array}$ & $\begin{array}{l}0 \\
0\end{array}$ & 3.82 & 1.179 \\
\hline 8 & $\begin{array}{l}\text { Organizations that adopt the concept of green } \\
\text { marketing create a positive mental image of } \\
\text { the consumer }\end{array}$ & $\begin{array}{l}\mathrm{Q} \\
\%\end{array}$ & $\begin{array}{l}11 \\
34\end{array}$ & $\begin{array}{l}14 \\
43.4\end{array}$ & $\begin{array}{l}7 \\
21.9\end{array}$ & $\begin{array}{l}0 \\
0\end{array}$ & $\begin{array}{l}0 \\
0\end{array}$ & 3.83 & 0.807 \\
\hline & General average & & & & & & & 3.79 & 1.128 \\
\hline
\end{tabular}

To verify the validity of this hypothesis, the Pearson Person correlation coefficient was used to measure the relationship between follow-up and knowledge of preventive management methods used by companies and between consumer protections.

The results of the analysis showed a positive correlation between follow-up and knowledge of preventive management methods used by companies and consumer protection. The correlation coefficient $(0.178)$, which is statistically significant at (0.05), was positive. And the knowledge of preventive management methods adopted by companies increased consumer protection, which indicates that there is a positive relationship between the follow-up and knowledge of preventive management methods used by companies and between consumer protections.

Second, there is a relationship between consumer awareness and protection for oneself.

Table 3. Arithmetical averages and standard deviations of the words of consumer awareness and awareness

\begin{tabular}{|c|c|c|c|c|c|c|c|c|c|}
\hline No & $\begin{array}{l}\text { Phrase } \\
\text { Degree of approval }\end{array}$ & & $\begin{array}{l}\text { Strongly } \\
\text { agree }\end{array}$ & Agree & Neutral & Disagree & strongly & $\begin{array}{l}\text { Ave } \\
\text { disagree } \\
\text { rage }\end{array}$ & Deviation \\
\hline 1 & $\begin{array}{l}\text { I recognize the important role of the } \\
\text { consumer and his contribution to the } \\
\text { preservation of the environment }\end{array}$ & $\begin{array}{l}\text { Q } \\
\%\end{array}$ & $\begin{array}{l}18 \\
56.3\end{array}$ & $\begin{array}{l}11 \\
34.4\end{array}$ & $\begin{array}{l}3 \\
9.4\end{array}$ & $\begin{array}{l}0 \\
0\end{array}$ & $\begin{array}{l}0 \\
0\end{array}$ & 4.08 & .0798 \\
\hline 2 & $\begin{array}{l}\text { I refuse to buy from products that are } \\
\text { harmful to the environment }\end{array}$ & $\begin{array}{l}\text { Q } \\
\%\end{array}$ & $\begin{array}{l}12 \\
37.5\end{array}$ & $\begin{array}{l}8 \\
25\end{array}$ & $\begin{array}{l}11 \\
34.4\end{array}$ & $\begin{array}{l}1 \\
3.1\end{array}$ & $\begin{array}{l}0 \\
0\end{array}$ & 3.98 & .933 \\
\hline 3 & $\begin{array}{l}\text { Social responsibility is an environmental } \\
\text { priority when I make a purchase }\end{array}$ & $\begin{array}{l}\mathrm{Q} \\
\%\end{array}$ & $\begin{array}{l}7 \\
21.9\end{array}$ & $\begin{array}{l}11 \\
34.4\end{array}$ & $\begin{array}{l}10 \\
31.3\end{array}$ & $\begin{array}{l}4 \\
12.5\end{array}$ & $\begin{array}{l}1 \\
0\end{array}$ & 4.16 & .745 \\
\hline 4 & $\begin{array}{l}\text { I realize that the resources of nature are } \\
\text { limited and must be preserved }\end{array}$ & $\begin{array}{l}\mathrm{Q} \\
\%\end{array}$ & $\begin{array}{l}22 \\
73.3\end{array}$ & $\begin{array}{l}6 \\
20\end{array}$ & $\begin{array}{l}2 \\
6.7\end{array}$ & $\begin{array}{l}0 \\
0\end{array}$ & $\begin{array}{l}0 \\
0\end{array}$ & 3.84 & 1.147 \\
\hline 5 & I always choose recyclable products & $\begin{array}{l}\mathrm{Q} \\
\%\end{array}$ & $\begin{array}{l}4 \\
13.3\end{array}$ & $\begin{array}{l}5 \\
16.7\end{array}$ & $\begin{array}{l}13 \\
43.3\end{array}$ & $\begin{array}{l}7 \\
23.3\end{array}$ & $\begin{array}{l}1 \\
3.3\end{array}$ & 3.96 & .875 \\
\hline 6 & $\begin{array}{l}\text { There is difficulty in obtaining } \\
\text { environmentally friendly products }\end{array}$ & $\begin{array}{l}\text { Q } \\
\%\end{array}$ & $\begin{array}{l}9 \\
29\end{array}$ & $\begin{array}{l}13 \\
41.9\end{array}$ & $\begin{array}{l}9 \\
29\end{array}$ & $\begin{array}{l}0 \\
0\end{array}$ & $\begin{array}{l}0 \\
0\end{array}$ & 4.22 & 1.017 \\
\hline 7 & $\begin{array}{l}\text { I respect laws and regulations aimed at } \\
\text { preserving the environment } \\
\text { General average }\end{array}$ & $\begin{array}{l}\mathrm{Q} \\
\%\end{array}$ & $\begin{array}{l}15 \\
48.4\end{array}$ & $\begin{array}{l}13 \\
42.9\end{array}$ & $\begin{array}{l}3 \\
9.7\end{array}$ & $\begin{array}{l}0 \\
0\end{array}$ & $\begin{array}{l}0 \\
0\end{array}$ & 4.02 & 1.079 \\
\hline
\end{tabular}


To verify this hypothesis, the Pearson correlation coefficient, was used to measure the relationship between consumer awareness and self-protection. The correlation coefficient $(0.239)$, which is statistically significant at (0.05), was positive. This means that the higher the awareness of the consumer, the greater the protection for himself, Indicating a positive relationship between consumer awareness and awareness and self-protection.

Third hypothesis: There is a relationship between educational level and increasing consumer awareness.

To validate this hypothesis, the "F" test was used to analyze the mono-variance to identify the relationship between the educational level and increase consumer awareness.

Table 4. The results of the single-variance analysis test to measure the relationship between educational level and increase consumer awareness

\begin{tabular}{llllllll}
\hline Tool & source & Total & Degrees of freedom & Average & F value & Application & Comment \\
\hline \multirow{2}{*}{ Consumer's awareness } & Among groups & 0.429 & 3 & 0.215 & 1.099 & 0.05 & function \\
& Within the group & 1.012 & 27 & 0.250 & & & \\
& total & 1.432 & 30 & & & & \\
& & & & & \\
\hline
\end{tabular}

It is clear from the above table that the differences between the averages reached the level of statistical significance, where the level of significance of the total degree of consumer awareness, according to the variable of the educational level (0.05) Thus we accept the hypothesis that there is a relationship between educational level and consumer awareness.

To find out the differences between the responses of the study sample and the total score of consumer awareness according to the educational level variable, the scheffe test was used to indicate the source of these differences.

Table 5. The Schiffe test to illustrate the source of the differences between the samples of the study in the total degree of consumer awareness according to the variable level of education

\begin{tabular}{|c|c|c|c|c|c|c|c|}
\hline The tool & age & $\begin{array}{l}\text { Arithmetic } \\
\text { mean }\end{array}$ & $\begin{array}{l}\text { Average } \\
\text { difference }\end{array}$ & $\begin{array}{l}\text { Primary } \\
\text { and } \\
\text { above }\end{array}$ & Diploma/Graduate & Studies & Intermediate/secondary \\
\hline \multirow{5}{*}{$\begin{array}{l}\text { Consumer's } \\
\text { awareness }\end{array}$} & Primary and above & 3.44 & & & & & 0.992 \\
\hline & & & & & & $1.2203 .521 *$ & \\
\hline & Diploma/Graduate & 4.62 & & & & 2.362 & 1.258 \\
\hline & Studies & 3.96 & & & & & 0.852 \\
\hline & Intermediate/secondary & 4.02 & & & & & \\
\hline
\end{tabular}

* There are significant differences at the level of 0.05 .

The above table shows the results of the Schiffe test for the responses of the sample of the study on the total degree of consumer awareness according to the variable of the educational level, which shows that there are statistically significant differences at the level of significance $(0.05)$ in the total degree of consumer awareness among those whose educational level (diploma / Their level of education (diploma / university) reached the average of their academic level (diploma / university) (4.62) which is the largest.

Therefore, we accept the assumption that there is a relationship between the level of education and increase consumer awareness for those who have educational level (diploma / university). This means that different educational levels have an impact on consumer awareness, that is, the higher the level of education, the greater the consumer awareness.

\section{Results and Recommendations:}

\subsection{Results}

The study reached a number of findings as follows:

1. There is a positive relationship between follow-up and knowledge of the preventive management methods used by companies, and between consumer protections. 
2. There is a positive relationship between awareness of the consumer and protecting himself.

3. There is a relationship between the educational level and increase consumer awareness for the benefit of those who are educational level (diploma / university).

4. Consumers set the environment standard in their preferences, for product selection in purchasing decisions.

5. The study indicated that the Saudi consumer has a high sense of responsibility towards the environment in general.

6. There is some change in attitudes and trends that support the environmental commitment of consumers.

7. Increased attention to the Environment at the global level, especially after the problems arising from neglect, and the consequent damage to the individual and society and other living organisms.

8. Environmental organizations are concerned about the environment, due to the pressures of stakeholders and beneficiaries of their outputs and the presence of strong international and regional legislation that obligates organizations to preserve and protect the environment in their various activities.

9. Adoption of business organizations to the concept of green marketing is a confirmation of their environmental orientation.

\subsection{Recommendations}

1. Universities and scientific institutes in the Kingdom, should take responsibility for protecting and improving the environment by opening environmental specialties, developing materials in the curricula and organizing training courses for employees of organizations and consumers, to contribute to increasing environmental awareness.

2. To compel the business organizations in the Kingdom to implement the laws related to the preservation of the environment.

3. Encourage consumers to adopt the values and culture of consumption of environmentally friendly goods through promotional messages directed to the consumer.

4. Establish a system to measure and control preventive management methods used by companies

5. To carry out guidance on the importance of the environment, and it's material and moral value by taking care of the process of recycling and contribution by the consumer.

6. Conduct specialized research and studies to understand the nature, characteristics and benefits of goods and services that are consistent with the concept of green marketing.

7. Great interest in environment, due to development and innovation activities of various community organizations, to create more concepts related to green marketing.

8. Benefit from the diversity and the multinational working environment available in companies operating in the Saudi market, to bring new ideas about green marketing.

9. Adoption of business organizations, to the concept of green marketing is a confirmation of their environmental orientation.

10. Organizations and companies should seek the necessary expertise and information, on how to apply the concept of green marketing and adjust their production processes to suit this concept in order to create a cleaner and pollution-free environment.

\section{Acknowledgments}

Thank God for helping us complete this research. And I thank all participants for answering the questionnaire.

\section{References}

Abderrahmane, A. (2014). The reality of green drug marketing in the pharmacy complex in Algeria. Journal of Economic Sciences, Management and Commercial Sciences, 12, 110-121.

Abu Rajab, M. (2011). Obstacles to Adopting Green Marketing by Organizations Working in Palestine. An-Najah University, Nablus, Palestine.

Badrawi, A. (2008). Activating Green Marketing in the Market-Based Environment Trends in Iraqi Business Organizations: An Exploratory Study. Al-Rafidain Development Journal, 89(30), 209-232.

Bakri, T. (2007). Green Marketing. Dar Al Yazuri, Amman, Jordan.

Dahmani, M. (2006). Marketing Service. Yousef Ben, Algeria Hedah University. 
Gureshi, H. S. (2011). Green Marketing as a Direction for Business Organizations in Achieving Sustainable Development, University of Wargala, Algeria.

Haddad, H. (2006). Fundamentals of Marketing. Dar Al-Hamid, Amman, Jordan.

Hamouda, M. (2014), The Relationship between Adopting the Concept of Green Marketing and Marketing Performance. Al-Azhar University.

Majid, A., \& Shaker, E. (n.d.). The Relationship between Green Marketing and Cleaner Production Strategy: Exploratory Study.

Mohammed, A. A. (2010). Green Marketing, Damascus University.

Shignia, A. (2010). Marketing and Logistics. University of Alageed, Algeria.

\section{Supplements}

Table of Pearson correlation coefficients between each term and total score

\begin{tabular}{lll}
\hline No. & Phrase & Correlation \\
\hline 1 & realized the importance of the role of consumers and their contribution to the preservation of the environment & $0.563^{* *}$ \\
2 & $\begin{array}{l}\text { The need for business organizations to apply the concept of green marketing to increase consumer awareness of social } \\
\text { responsibility towards environmental protection }\end{array}$ & $0.351^{* *}$ \\
3 & $\begin{array}{l}\text { There is a significant trend and role of the state in activating the application of green marketing in business } \\
\text { organizations }\end{array}$ & $0.275^{*}$ \\
4 & $\begin{array}{l}\text { Increase awareness of the consumer of social responsibility towards the protection of the environment for the reasons } \\
\text { of interest of organizations, in the need to apply the concept of green marketing }\end{array}$ & $0.260^{*}$ \\
5 & Marketing of recycled products assists and supports the national economy & $0.378^{* *}$ \\
6 & I am willing to pay a higher price if the products are environmentally friendly & $0.501^{* *}$ \\
7 & I refuse to buy from products that harm the environment & $0.542^{* *}$ \\
8 & Organizations that adopt the concept of green marketing create a positive mental image of the consumer & $0.689^{* *}$ \\
9 & The CSR criterion is an environmental priority when I buy & $0.559^{* *}$ \\
10 & Saudi business organizations are keen to design products that meet the requirements of the environment & $0.741^{* *}$ \\
11 & I understand that the resources of nature are limited and must be maintained & $0.220^{*}$ \\
12 & It is possible to change my trademark brand for environmental reasons & $0.478^{* *}$ \\
13 & Always select recyclable products & $0.181^{*}$ \\
14 & There is a difficulty in obtaining environmentally friendly products & $0.387^{* *}$ \\
15 & There is weakness in the mechanisms used to enhance the role of organizations in protecting the environment and & $0.621^{* *}$ \\
& increasing consumer awareness & $0.452^{* *}$ \\
16 & I respect laws and regulations aimed at preserving the environment &
\end{tabular}

** Statistical function at level $(0.01) *$ Statistical function at the level $(0.05)$

\section{Copyrights}

Copyright for this article is retained by the author(s), with first publication rights granted to the journal.

This is an open-access article distributed under the terms and conditions of the Creative Commons Attribution license (http://creativecommons.org/licenses/by/4.0/). 